\title{
Hematological parameters and nuclear abnormalities in peripheral erythrocytes of Achirus lineatus (Pleuronectiformes: Achiridae)
}

\author{
Lílian R. G. B. Prado • Cristiane Felix • Denis M. S. Abessa • Lucas M. Buruaem • \\ Laís D. Abujamara • Aline A. Kirschbaum • Gabriela C. R. Turatti • \\ Maria J. T. Ranzani-Paiva • Aristides T. Correia • Robson Seriani
}

Received: 17 September 2013 / Accepted: 7 January 2014 / Published online: 31 January 2014

(C) Springer-Verlag London 2014

\begin{abstract}
Hematological parameter of demersal fish constitutes important measures of biological effects of seasonality and contaminants in sediments. We aimed to assess the hematological parameters and nuclear abnormalities, including micronuclei levels, in peripheral erythrocytes of flatfish Achirus lineatus collected in São Vicente Estuary in summer and winter. The number of lymphocytes was significantly higher in summer, whereas the number of neutrophils was
\end{abstract}

L. R. G. B. Prado $\cdot$ C. Felix · G. C. R. Turatti $\cdot$ R. Seriani $(\bowtie)$

Universidade Paulista (UNIP), Campus Paraíso. R. Vergueiro, 1211, 01504001 São Paulo, SP, Brazil

e-mail: robsonseriani@yahoo.com.br

D. M. S. Abessa

Campus Experimental do Litoral Paulista, Universidade Estadual Paulista (UNESP), Praça Infante Dom Henrique, s/n,

11330-900 São Vicente, SP, Brazil

\section{M. Buruaem}

Instituto de Ciências do Mar (LABOMAR-UFC), Universidade Federal do Ceará, Av. da Abolição, 3207, 60165-081 Fortaleza, CE, Brazil

\section{D. Abujamara}

Universidade Santa Cecília (UNISANTA), R. Oswaldo Cruz, 277, 11045-907 Santos, SP, Brazil

\section{A. A. Kirschbaum \\ Instituto Oceanográfico, Universidade de São Paulo, Praça do \\ Oceanográfico, 191, 05508-900 São Paulo, SP, Brazil}

\section{J. T. Ranzani-Paiva}

Instituto de Pesca, Av. Francisco Matarazzo, 455,

05001-000 São Paulo, SP, Brazil

\author{
A. T. Correia $\cdot$ R. Seriani \\ Faculdade de Medicina, Universidade de São Paulo, São Paulo, SP, \\ Brazil
}

significantly higher in winter. For other measured parameters, no significant differences were observed in spite of the levels of erythroblasts, leukocytes, thrombocytes, micronuclei and nuclear abnormality tended to be slightly higher in winter. Integrated analysis of data suggests that genotoxicity may be related to immunosuppression, although some types of leukocytes appear to act removing anomalous cells. Considering the contamination status of the Santos-São Vicente Estuarine system, the results provide an important contribution to knowledge of the hematological aspects of A.lineatus and its potential use as a bioindicator for monitoring estuarine sites.

Keywords Flatfish · Hematology $\cdot$ Biomarkers ·

Seasonality $\cdot$ Estuary

\section{Introduction}

Demersal fishes play an important role in food web of marine ecosystems, as they feed on benthic invertebrates and small fish, transferring energy and biomass to higher levels of the trophic web (Munroe 2007). Among them, the subtropical flatfish Achirus lineatus presents an intimate relationship with benthic environment as it presents a burrowing behavior (Chaves and Serenato 1998) and feeds on benthic organisms, thus increasing the exposure to hypoxic conditions and to environmental contamination, since sediments are recognized as a sink and secondary source of chemicals in aquatic systems (Burton and Johnston 2010).

Flatfishes have been used as biological models to study the effects of contamination (Moore 1992; Riba et al. 2004), as in field surveys through laboratorial sediment toxicity testing. Such studies have considered effects at biochemical, bioaccumulation, cellular, histological and also lethality of exposed 
organisms (Moore 1992; Moore and Evans 1992; Belpaeme et al. 1998; Stentiford et al. 2005; Polak-Juszczak 2012).

Alterations of hematological parameters and presence of micronuclei (MN) and other nuclear abnormalities (NA) constitute relevant indicators of responses of fishes exposed to stressing agents because such changes may be associated to diseases, environmental variations (including contamination) and physiological status, and thus they may be considered an overall indicator of health of fishes (Tavares-Dias and Moraes 2004; Osman et al. 2012; Massar et al. 2012; Seriani and Ranzani-Paiva 2012; França et al. 2013). This approach has been used worldwide to assess the responses of fishes to pollutants as in laboratorial experiments with single and mixtures of contaminants in environmental assessments (Al-Sabti and Metcalfe 1995; Kirschbaum et al. 2009; Seriani and Ranzani-Paiva 2012). However, hematological changes and MN may be induced by natural causes, such as seasonality, temperature and salinity changes, reproductive cycle, feeding status, among others (Blaxhall 1972; Duthie and Tort 1985; Ogbulie and Okpokwasili 1999; Tavares-Dias and Moraes 2004; Tavares-Dias et al. 2011; Martins et al. 2010; Seriani and Ranzani-Paiva 2012; Seriani et al. 2013). Thus, the use of this approach in environmental studies requires previous knowledge on the ranges each cell type are expected to occur and how they respond to natural and anthropic factors.

The objective of this study is to evaluate the hematological parameters and micronuclei and nuclear abnormalities (Blebbed, Lobed, Vacuolated and Notched) in peripheral erythrocytes of the flatfish $A$. lineatus collected in São Vicente Estuary in two seasons, aiming to provide information to support the use of this species as a suitable biomonitor of environmental contamination.

\section{Material and methods}

The fish individuals were collected at São Vicente Estuary (SVE) $\left(23^{\circ} 30^{\prime}-24^{\circ} \mathrm{S}-46^{\circ} 05^{\prime}-46^{\circ} 30^{\prime} \mathrm{W}\right)$. This area receives discharges of sewage and contributions of contaminants from industrial areas, marinas and percolated leachates from irregular domestic and industrial landfills (Lamparelli et al. 2001). According to Sampaio et al. (2008), the SVE presents the worst indicators of fecal pollution on the coast of São Paulo. Moreover, moderate to high concentrations of metals $(\mathrm{Cd}, \mathrm{Ni}$, $\mathrm{Cu}, \mathrm{Zn}, \mathrm{Cr}$ ) and organochlorines were observed in aquatic organisms and sediments from SVE (Abessa et al. 2008; Lamparelli et al. 2001; Carmo et al. 2011).

Flatfish individuals (A. lineatus) with length: $12.0 \pm 1.0 \mathrm{~cm}$ and weight: $62.7 \pm 5.2 \mathrm{~g}$ were captured by $5^{\prime}$ trawl fishery during winter $(n=15)$ and summer $(n=15)$ at SVE, transferred to plastic boxes containing seawater from the estuary and immediately taken to laboratory, where they were acclimated in ambient temperature and at a density of $1 \mathrm{~g}$ fish/L with continuous aeration for at least $4 \mathrm{~h}$ to reduce stress. Then, the fishes were anesthetized with benzocaine (3\%), measured and weighed, and then, blood samples were withdrawn from the caudal vein with heparinized syringes. Blood processing was immediately initiated after collections.

Blood extensions ( $\cong 50 \mu \mathrm{L}$ of blood) were prepared in glass slides and stained with May-Grünwald-Giemsa (Rosenfeld 1947), and the specific counts were analyzed per slide/ animal under an optical microscope $(1,000 \times)$. First extensions were used for the analysis of leukocytes (neutrophils, monocytes, lymphocytes, basophyls and eosinophyls) expressed in percentage. In the second set of extensions, 2,000 cells were analyzed per slide/specimen for micronuclei (MN) and nuclear abnormality (NA) rates, considering Blebbed, Lobed, Vacuolated and Notched nuclei. These extensions were also used to count erythroblasts (ERB), total leukocytes (TLC) and thrombocytes (TRB), according to the indirect method adopted by Hrubec and Smith (1998); in this case, 2,000 cells were analyzed as well.

Correlation tests were used to identify interactions between cell types under the influence of seasonality. The measured parameters were expressed as means \pm standard errors (S.E.), and statistical analyses consisted in comparing the results of winter and summer by using Student's $t$-test with $p<0.05$.

Water sample aliquots were taken from the acclimation tanks, and salinities, $\mathrm{pH}$ values and temperatures $\left({ }^{\circ} \mathrm{C}\right)$ were measured. These physical-chemical parameters of water samples collected in São Vicente Estuary in summer and winter are presented in Table 1. Variation was relatively low between seasons, even considering tidal cycles, and salinities were $\geq 25$ $\%$; $\mathrm{pH}$ values ranged between 7.3 (winter) and 7.6 (summer), and temperatures were higher than $21^{\circ} \mathrm{C}$.

\section{Results}

Regarding the differential leukocyte accounting (Fig. 1), significant differences were observed for percentages of lymphocytes and neutrophils in summer when compared to winter results $(p=0.03)$. Lymphocytes were more numerous in summer $(62.75 \% \pm)$ than in winter $(16.3 \pm)$, whereas the number of neutrophils was greater in winter $(75.95 \pm$ against $16.3 \pm$ ). The number of monocytes, eosinophils and basophils was generally low in both periods (summer: monocytes $(6.25 \pm$ 4.08), eosinophils $(2.15 \pm 1.81)$ and basophils $(0.45 \pm 0.66)$;
Table 1 Physicalchemical parameters of water samples collected in São Vicente Estuary in summer and winter

\begin{tabular}{lll}
\hline Parameters & Summer & Winter \\
\hline Salinity & 25 & 27 \\
$\mathrm{pH}$ & 7.6 & 7.3 \\
Temperature $\left({ }^{\circ} \mathrm{C}\right)$ & 24.0 & 21.5 \\
\hline
\end{tabular}


Fig. 1 Mean percentages of peripheral leukocytes of Achirus lineatus from São Vicente Estuary in summer and winter. Asterisks indicate significant differences $(p<0.05)$ between summer and winter

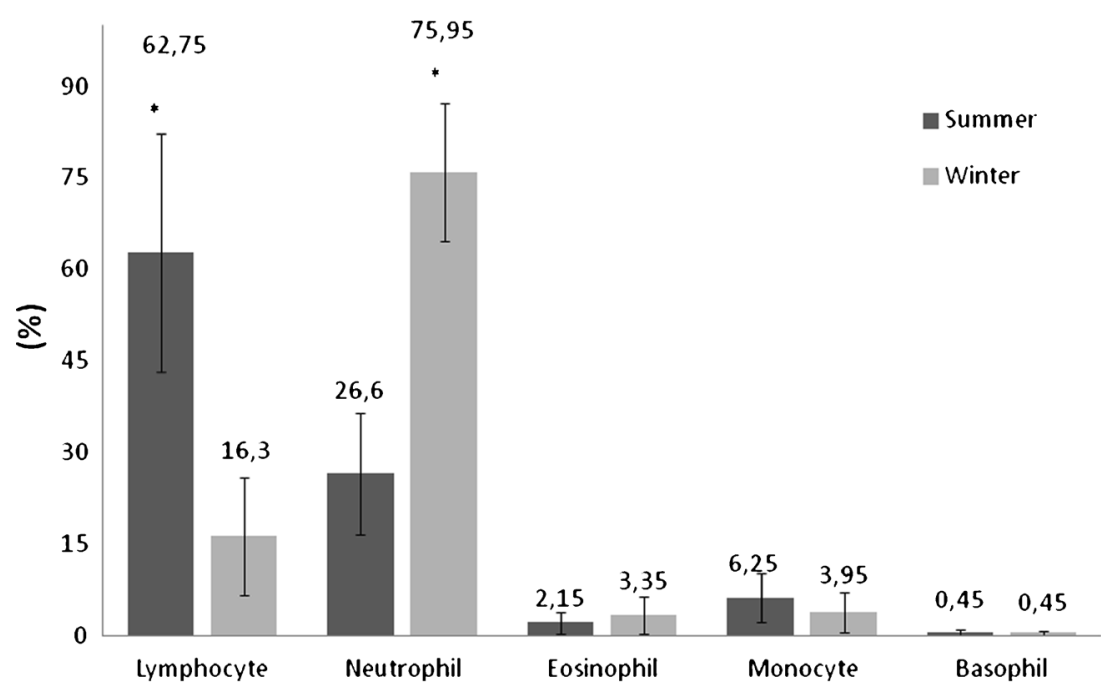

winter: monocytes $(3.95 \pm 3.28)$, eosinophils $(1.81 \pm 3.09)$ and basophils $(0.45 \pm 0.39))$.

On the other hand, although not statistically different, the percentages of erythroblasts, leukocytes, thrombocytes, micronuclei and other nuclear abnormality of $A$. lineatus collected in winter tended to be slightly higher than those observed in summer (Fig. 2), suggesting worse conditions in winter.

Figure 3 shows cellular types measured in this study. The red blood cells of fish have similar shapes and sizes and often are oval shaped and have a central nucleus with acidophilic cytoplasm. They are nucleated and red pigmented because they carry hemoglobin (Tavares-Dias and Moraes 2004). Fish thrombocytes come in a variety of shapes, and they may be elliptic, rounded, oval shaped or fusiform (Ranzani-Paiva and Silva-Souza 2004) with acidophilic cytoplasm. Their nucleus is often large, and cytoplasm is scarce. Because of these features, they are sometimes confused with lymphocytes. These cells appear either as single cells or grouped together (Vázquez and Guerrero 2007). Leukocytes are nonpigmented, nucleated cells whose primary function is to combat infections and cellular debris, and they may assume different types: lymphocytes are spherical, with a rounded nucleus and strongly basophilic cytoplasm; monocytes are large cells, apparently with phagocytosis functions (Ranzani-Paiva and Silva-Souza 2004); neutrophils are rounded, with a segmented nucleus, and may be frequent in the blood of some fish species. Eosinophils and basophils are scarce and sometimes absent in the blood of fish, and their function is not well understood.

In the summer sampling, the only significant correlation among measured parameters occurred between micronuclei $\times$
Fig. 2 Mean numbers of erythroblasts, leukocytes, thrombocytes, micronuclei and nuclear abnormality in 1,000 peripheral cells of Achirus lineatus from São Vicente Estuary

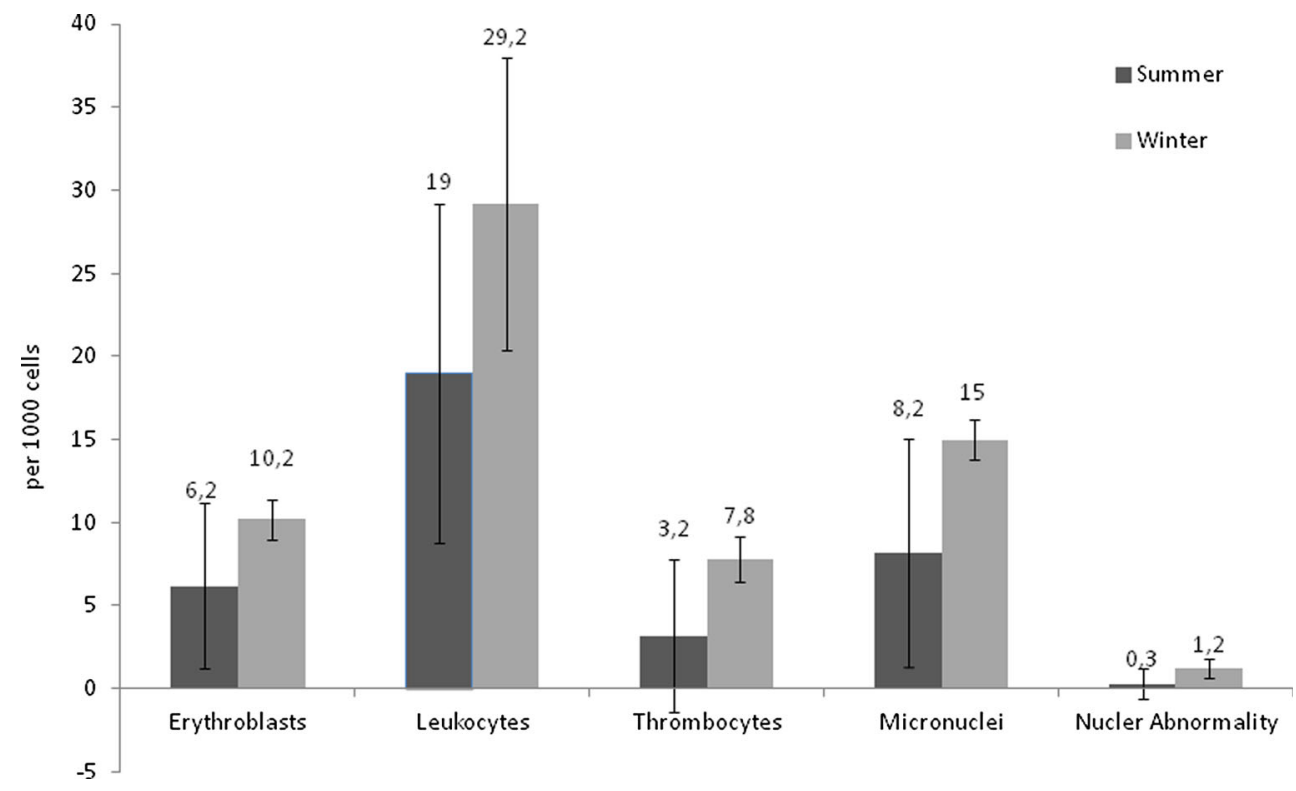


Fig. 3 Peripheral cells of Achirus lineatus. a Lymphocyte. $\mathbf{b}$

Neutrophil. c Eosinophil. d

Basophil. e Monocyte. f

Thrombocyte. g Erythroblasts. h

Lobed nuclei. i Blebbed nuclei. $\mathbf{j}$

Micronuclei. k Notched nuclei
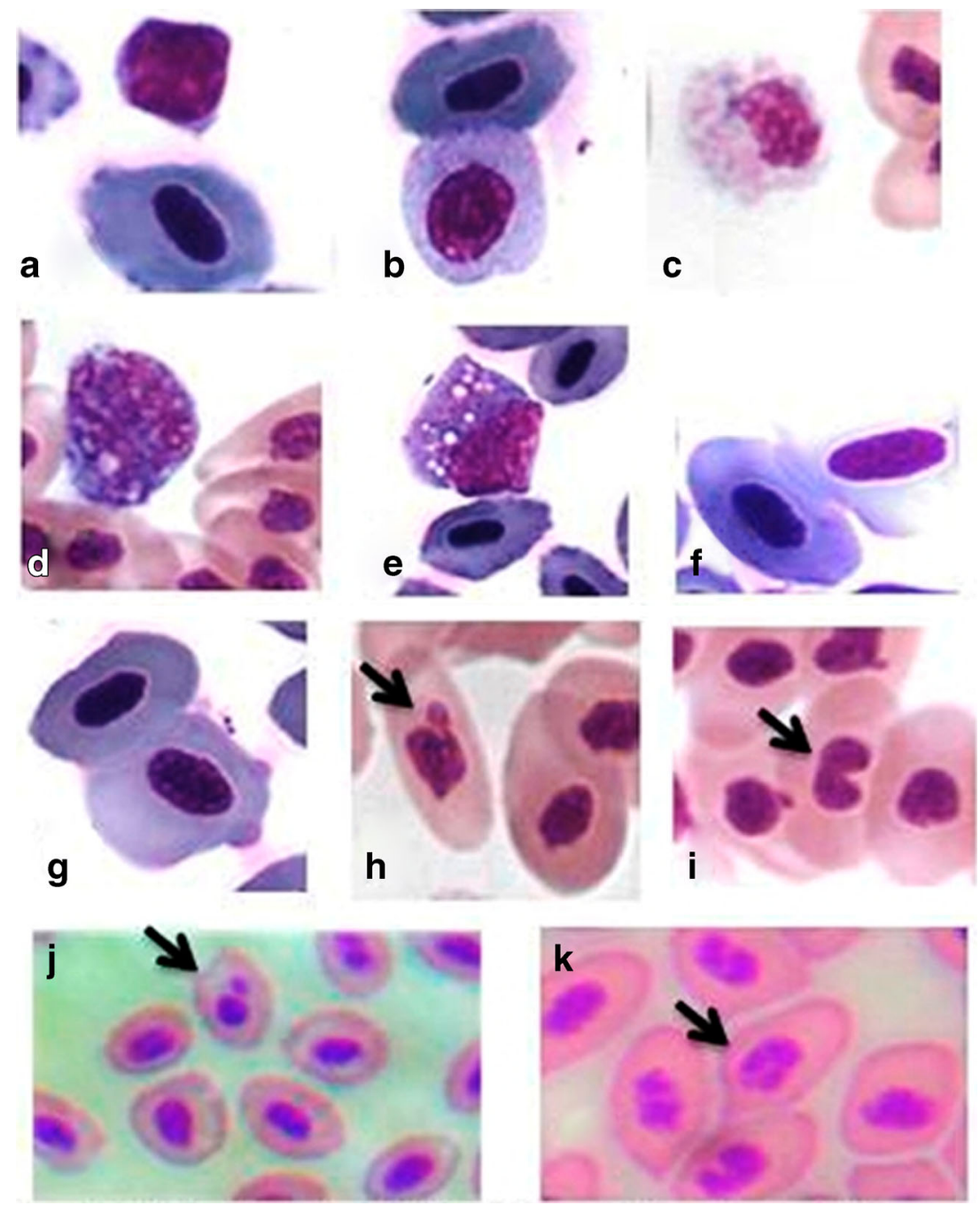

TLC $(r=-0.70 ; p=0.02)$. In winter, positive correlations were observed for neutrophil $\times$ eosinophil $(r=0.72 ; p=0.01) ; \mathrm{MN} \times$ NA $(r=0.67 ; p=0.01) ; \mathrm{MN} \times$ neutrophil $(r=0.76 ; p=0.01)$; NA $\times$ monocyte $(r=0.83 ; p=0.001)$. Negative correlations were observed between neutrophil $\times$ lymphocyte $(r=-0.88$; $p=0.01) ; \mathrm{TLC} \times \mathrm{NA}(r=-0.84 ; p=0.02)$; erythroblasts $\times$ eosinophil $(r=-0.88 ; p=0.001)$; TLC $\times$ neutrophil $(r=-0.60 ; p=$ $0.04)$; NA $\times$ eosinophil $(r=-0.68 ; p=0.02)$.

\section{Discussion}

In summer, MN and WBC were negatively correlated. Such response may be a signal that leukocytes are related to the removal of anomalous or damaged cells, as observed by John et al. (2007). Another hypothesis for this correlation is that stressing agents may induce DNA damage (Normann et al. 2008; Kirschbaum et al. 2009; Osman et al. 2012; Kurteshi and Letaj 2013) and immunosuppression (Houston 1990;
Wepener et al. 1992; Danion et al. 2011; Seriani et al. 2011), which is suggested by the lower TLC number.

In winter, positive correlations between NA and $\mathrm{MN}, \mathrm{MN}$ and neutrophil, NA and monocyte and neutrophil and eosinophil may be evidencing that these leukocytes are removing anomalous cells with DNA damage. However, the increased number of some types of leukocytes and indicators of DNA damage may be due to the action of a stressing agent.

Differential leukocyte accounting showed significant decrease of the percentage of lymphocytes in winter and of neutrophils in summer $(p<0.05)$. White blood cell levels (as neutrophils and lymphocytes) respond to temperature changes, and this probably may explain such results, since water temperature variation may interfere with immune response due to ectothermic metabolism (Tavares-Dias and Moraes 2004). The increase in the percentages of neutrophils in winter may be related to periods of low temperatures (Ainsworth et al. 1991). Although leukocytes have been described as more resistant to changing temperatures, our 
study suggests that actually neutrophils can be related to stress due to lower temperature instead of all TLC cells. On the other hand, freshwater species such Oreochromis niloticus (Seriani et al. 2011), Alburnoides bipunctatus and Cyprinion macrostomus (Örün et al. 2003) showed a neutrophil increase only in summer, which is the opposite of results obtained in this investigation. Further studies are required to understand the causes of such discrepancy, which may be related to specific mechanisms of regulation in the face of external stress inductors.

Also, the decrease in the number of lymphocytes in winter probably was influenced by seasonal conditions (especially in the cooler temperatures) due to the action of adrenocorticotropic hormone (ACTH) and cortisol production, and mitogenic activity of cells (Ellis 1981). These hormones inhibit production of defense cells, thus inducing immunosuppression (Adamante et al. 2008; Diniz and Honorato 2012). Similar results were found for a catfish species (Dexiang and Ainsworth 1991).

Comparing results for summer and winter, no significant differences were observed between the numbers of erythroblasts, leukocytes, thrombocytes, micronuclei and nuclear abnormalities in A. lineatus from São Vicente Estuary; however, mean values tended to be higher in winter. Such higher numbers of NA and MN may suggest a slightly worse environmental conditions in winter. Seasonality may affect differently each species of fish, as well as environmental factors such as contamination, leading to changes in erythropoiesis and leucopoiesis. Under stressing conditions, the reduction of circulating lymphocytes is the most common change in hematological parameters, possibly due to its redistribution between organs or also due to lymphopoietic activity. In this study, the lower number of lymphocytes in winter corroborates to that pattern, accompanied by increased numbers of neutrophils (Tavares-Dias and Moraes 2004).

Influence of seasonality and pollution was observed in the expression of micronuclei frequencies in Centropomus parallelus and Cathorops spixii from Cananéia-Iguape Estuarine Complex; however, the regime of such estuary combines rainy season (summer), producing low salinities and higher loadings of metals via suspended particles, making it very difficult to separate the natural and anthropic effects on $\mathrm{MN}$ and NA (Kirschbaum et al. 2009; Kuniyoshi and Braga 2011). Anyway, MN and NA alterations were due to natural factors as it is well known that micronuclei and nuclear abnormality formation can occur spontaneously or be induced by environmental changes or pollution (Al-Sabti and Metcalfe 1995; Rybakovas et al. 2009; Kuniyoshi and Braga 2011; Osman et al. 2012; Kurteshi and Letaj 2013).

São Vicente Estuary is considered degraded (Lamparelli et al. 2001; Cesar et al. 2012; Abessa et al. 2008; Hortellani et al. 2008; Azevedo and Braga 2011; Pereira et al. 2012; Seriani et al. 2013; Buruaem et al. 2013) due to human occupation and discharges of sewage, residues of marinas and urban drainage, which produce sediment contamination (Medeiros and Bícego 2004; Bícego et al. 2006; Hortellani et al. 2008; Azevedo and Braga 2011; Buruaem et al. 2013) and incidence of biological effects (Abessa et al. 2008; Cesar et al. 2007; Seriani et al. 2011; Azevedo et al. 2012; Maranho et al. 2012; Seriani et al. 2013). However, results obtained in this investigation do not allow distinguishing if hematological changes were due to natural or anthropic factors. In this sense, it is possible that the observed effects are a product of a combination between them. Further studies are required to elucidate the causes of such variations and to allow evaluating if hematology of $A$. lineatus may be considered a good biomarker of environmental contamination.

Acknowledgments The authors gratefully acknowledge Mr. Ricardo for his assistance with the fish sampling. L.M. Buruaem ( $\mathrm{PhD}$ grant 142002/2010-0) and D.M.S. Abessa (552299/2010-3) were sponsored by CNPq.

\section{References}

Abessa DMS, Carr RS, Sousa ECPM, Rachid BRF, Zaroni LP, Pinto YA, Gasparro MR, Bícego MC, Hortellani MA, Sarkis JES, Muniz P (2008) Integrative ecotoxicological assessment of a complex tropical estuarine system. In: Hoffer TN (ed) Marine pollution: new research. Nova Science, New York, pp 125-159

Adamante WB, Nuñer APO, Barcellos LJG, Soso AB, Finco JA (2008) Stress in Salminus brasiliensis fingerlings due to different densities and times of transportation. Arq Bras Med Vet Zootec 60(3):755761

Ainsworth AJ, Dexiang C, Waterstratt PR, Greenway T (1991) Effect of temperature on the immune system of channel catfish (Ictalurus punctatus). I. Leukocyte distribution and phagocyte function in the anterior kidney at $10^{\circ} \mathrm{C}$. Comp Bioch Physiol 100A:907-912

Al-Sabti K, Metcalfe CD (1995) Fish micronuclei for assessing genotoxicity in water. Mutat Res 343:121-135

Azevedo JS, Braga ESG (2011) Caracterização hidroquímica para qualificação ambiental dos estuários de Santos-São Vicente e Cananéia. Arq Ciênc Mar 44:1-10

Azevedo JS, Sarkis JES, Oliveira T, Urich J (2012) Tissue-specific mercury concentrations in two catfish species from the Brazilian Coast. Braz J Oceanogr 60(2):209-217

Belpaeme K, Cooreman K, Kirsch-Volders M (1998) Development and validation of the in vivo alkaline comet assay for detecting genomic damage in marine flatfish. Mutat Res 415(3):167-184

Bícego MC, Taniguchi S, Yogui GT, Montone RC, Silva DAM, Lourenço RA, Martins CC, Sasaki ST, Pellizari VH, Weber RR (2006) Assessment of contamination by polychlorinated biphenyls and aliphatic and aromatic hydrocarbons in sediments of the Santos and São Vicente Estuary System, São Paulo, Brazil. Mar Pollut Bull 52:1784-1832

Blaxhall PC (1972) The haematological assessment of the health of fresh water fish. A review of selected literature. J Fish Biol 4:593-604

Burton GA, Johnston EL (2010) Assessing contaminated sediments in the context of multiple stressors. Environ Toxicol Chem 29:2625-2643

Buruaem LM, de Castro IB, Hortellani MA, Taniguchi S, Fillmann G, Sasaki ST, Petti MAV, Sarkis JES, Bícego MC, Maranho LA, Davanso MB, Nonato EF, Cesar A, Costa-Lotufo LV, Abessa 
DMS (2013) Integrated quality assessment of sediments from harbour areas in Santos-São Vicente Estuarine System, Southern Brazil. Estuar Coast Shelf Sci 130:179-189. doi:10.1016/j.ecss. 2013.06.006

Carmo CA, Abessa DMS, Machado-Neto JG (2011) Metais em águas, sedimentos e peixes coletados no Estuário de São Vicente, SP, Brasil. O Mundo da Saúde 35(1):64-70

Cesar A, Choueri RB, Riba I, Morales-Caselles C, Pereira CDS, Santos AR, Abessa DMS, Delvalls TA (2007) Comparative sediment quality assessment in different littoral ecosystems from Spain (Gulf of Cadiz) and Brazil (Santos and São Vicente Estuarine System). Environ Int 33(4):429-435

Cesar A, Choueri RB, Gusso-Choueri PK, Pereira CDS (2012) Integrative approach for the environmental quality assessment of aquatic ecosystems: a critical review. Global J Environ Sci Techn 1:2-9

Chaves PTC, Serenato A (1998) Diversidade de dietas na assembleia de linguados (Teleostei: Pleuronectiformes) do manguezal da Baía de Guaratuba, Paraná, Brasil. Rev Bras Oceanogr 46(1):61-68

Danion M, Le Floch S, Kanan R, Lamour F, Quentel C (2011) Effects of in vivo chronic hydrocarbons pollution on sanitary status and immune system in sea bass (Dicentrarchus labrax L.). Aquat Toxicol 105(3-4):300-311

Dexiang C, Ainsworth J (1991) Effect of temperature on the immune system of channel catfish (Ictalarus punctatus) II. Adaptation of anterior kidney phagocytes to $10^{\circ} \mathrm{C}$. Comp Biochem Physiol Part A 100(4):913-918

Diniz NM, Honorato CA (2012) Algumas alternativas para diminuir os efeitos do estresse em peixes de cultivo - revisão. Arq Ciên Vet Zool da UNIPAR 15(2):149-154

Duthie GC, Tort L (1985) Effects of dorsal artic carrulation on the respiration and haematology of the Mediterranean dog-fish Segliorhinus canicula. Comp Biochem Physiol Part A 81:879-883

Ellis AE (1981) Inmunology of teleosts. In: Roberts RJ (ed) Fish pathology, 2nd edn. Bailliere Tindall, London, pp 103-117

França JG, Ranzani-Paiva MJT, Lombardi J, Carvalho S, Filipak-Neto F, Oliveira-Ribeiro CA (2013) Toxic effect of potassium permanganate on Oreochromis niloticus based on hematological parameters and biomarkers of oxidative stress. Int J Fish Aquacult 5(1):1-6

Hortellani MA, Sarkis JES, Abessa DMS, Souza ECPM (2008) Avaliação da contaminação por elementos metálicos dos sedimentos do estuário Santos-São Vicente. Quim Nova 31(1):10-19

Houston AH (1990) Blood and circulation. In: Schreck C, Moyle B (eds) Methods in fish biology. American Fisheries Society, Bethesda (MD), pp 273-334

Hrubec TC, Smith SA (1998) Hematology of fish. In: Feldman BF, Zinkl JG, Jain NC (eds) Schalm's veterinary hematology, 5th edn. W.W. Lippincott, Sydney, Australia, pp 1120-1125

John PJ (2007) Alteration of certain blood parameters of freshwater teleost Mystus vittatus after chronic exposure to Metasystox and Sevin. Fish Physiol Biochem 33(1):15-20

Kirschbaum AA, Seriani R, Pereira CDS, Assunção A, Abessa DMS, Rotundo MM, Ranzani-Paiva MJ (2009) Citogenotoxicity biomarkers in fat sook Centropomus parallelus from Cananeia and São Vicente estuaries, SP, Brazil. Genet Mol Biol 32(1):151-154

Kuniyoshi LS, Braga ES (2011) Cytogenetic disruption in fishes as bioindicator of the environmental quality in two estuarine systems under different exposition to anthropogenic influences. Safety Health Environ World Congress 25(28):93-96

Kurteshi K, Letaj K (2013) Assessment of the piscine micronucleus test as an in situ biological indicator of fungicide contaminant effects. J Chem Biol Phys Sci 3(2):1263-1267

Lamparelli ML, Costa MP, Prosperi VA, Bevilacquia JE, Araujo RPA, Eysink GGL, Pompeia S (2001) Sistema Estuarino de Santos e São Vicente. Relatório Técnico CETESB, São Paulo, SP, 178p. Available at. http://www.cetesb.sp.gov.br/Agua/relatorios/rel sist estuarino/relatorio.zip. (accessed in November 20th, 2013)
Maranho LA, Pereira CDS, Choueri RB, Cesar A, Gusso-Choueri PK, Torres RJ, Abessa DMS, Morais RD, Mozeto AA, DelValls TA, Martín-Díaz ML (2012) The application of biochemical responses to assess environmental quality of tropical estuaries: field surveys. J Environ Monitor 14:2608-2615

Martins CC, Bícego MC, Mahiques MM, Figueira RCL, Tessler MG, Montone RC (2010) Depositional history of sedimentary linear alkylbenzenes (LABs) in a large South American industrial coastal area (Santos Estuary, Southeastern Brazil). Environ Pollut 158: 3355-3364

Massar B, Dey S, Barua R, Dutta K (2012) Microscopy and microanalysis of hematological parameters in common carp, Cyprinus carpio, inhabiting a polluted lake in North East India. Microsc Microanal 18:1077-1087

Medeiros PM, Bícego MC (2004) Investigation of natural and anthropogenic hydrocarbon inputs in sediments using geochemical markers. I. Santos, SP-Brazil. Mar Pollut Bull 49:761-769

Moore MN (1992) Molecular cell pathology of pollutant-induced liver injury in flatfish: use of fluorescent probes. Mar Ecol Progr Ser 91: $127-133$

Moore MN, Evans B (1992) Detection of ras oncoprotein in liver cells of flatfish (dab) from a contaminated site in the North Sea. Mar Environ Res 34:33-38

Munroe TA (2007) Tropical flatfish fisheries. In: Gibson RN (ed) Flatfishes: biology and exploitation. Blackwell Science Ltd, Oxford, UK. doi:10.1002/9780470995259.ch13

Normann CABM, Moreira JCF, Cardoso VV (2008) Micronuclei in red blood cells of armored catfish Hypostomus plecotomus exposed to potassium Dichromate. African J Biotechnol 7(7):893-896

Ogbulie JN, Okpokwasili GC (1999) Haematological and histological responses of Clarias gariepinus and Heterobranchus bidon salis to some bacterial disease in Rivers State, Nigeria. J Nat Sci Found Sri Lanka 27:1-16

Örün I, Dörücü M, Yazlak H (2003) Hematological parameters of three cyprinid fish species from Karakaya Dam lake, Turkey. OnLine J Biol Sci 3(3):320-328

Osman AG, Abuel-Fadl KY, Kloas W (2012) In situ evaluation of the genotoxic potential of the river Nile: II. Detection of DNA strandbreakage and apoptosis in Oreochromis niloticus (Linnaeus, 1758) and Clarias gariepinus (Burchell, 1822). Mutat Res 747(1): 14-21

Pereira CDS, Martín-Díaz ML, Catharino MGM, Cesar A, Choueri RB, Taniguchi S, Abessa DMS, Bícego MC, Vasconcellos MBA, Bainy ACD, Sousa ECPM, Delvalls TA (2012) Chronic contamination assessment integrating biomarkers' responses in transplanted mussels - a seasonal monitoring. Environ Toxicol 27:257-267

Polak-Juszczak L (2012) Bioaccumulation of mercury in the trophic chain of flatfish from the Baltic Sea. Chemosphere 89(5):585-591

Ranzani-Paiva MJT, Silva-Souza A (2004) Hematologia de peixes Brasileiros. In: Ranzani-Paiva MJT, Takemoto RM, Lizama MAP (eds) Sanidade de organismos aquáticos. Varela, São Paulo, Brazil, pp 89-120

Riba I, Casado-Martínez C, Forja JM, Delvalls TA (2004) Sediment quality in the Atlantic coast of Spain. Environ Toxicol Chem 23: 271-282

Rosenfeld G (1947) Corante pancrômico para hematologia e citologia clínica. Nova combinação dos componentes do May-Grünwald e do Giemsa num só corante de emprego rápido. Mem Instit Butantan 20: 329-334

Rybakovas A, Baršiene J, Lang T (2009) Environmental genotoxicity and cytotoxocity in the offshore zones of the Baltic and the North Seas. Mar Environ Res 68:246-256

Sampaio AFP, Mateus M, Berzin G (2008) A modelling approach to the study of faecal pollution in the Santos Estuary. In: Neves R, Baretta JW, Mateus M (eds) Perspectives on integrated coastal zone management in South America. IST Press, Lisboa, Portugal, pp 425-434 
Seriani R, Ranzani-Paiva MJT (2012) Alterações hematológicas em peixes: aspectos fisiopatológicos e aplicações em ecotoxicologia aquática, vol 1. In: Silva-Souza AT, Lizama MAP, Takemoto RM, (Eds). Alterações hematológicas em peixes: aspectos fisiopatológicos e aplicações em ecotoxicologia aquática. $1^{\mathrm{a}} \mathrm{ed}$. Massoni, Maringá, pp 221-242

Seriani R, Abessa DMS, Kirschbaum AA, Pereira CDS, Romano P, Ranzani-Paiva MJT (2011) Relationship between water toxicity and hematological changes in Oreochromis niloticus. Braz J Aq Sci Technol 15(2):47-53

Seriani R, Abessa DMS, Pereira CDS, Kirschbaum AA, Assunção A, Ranzani-Paiva MJT (2013) Influence of seasonality and pollution on the hematological parameters of the estuarine fish Centropomus parallelus. Braz J Oceanography 61:105-111

Stentiford GD, Viant MR, Ward DG, Johnson PJ, Martin A, Wenbin W, Cooper HJ, Lyons BP, Feist SW (2005) Liver tumors in wild flatfish: a histopathological, proteomic, and metabolomic study. OMICS 9(3):281-299

Tavares-Dias M, Moraes FR (2004) Hematologia de peixes teleósteos, 1st edn. Villimpress Complexo Gráfico, Ribeirão Preto, p 144

Tavares-Dias M, Monteiro AMC, Affonso EG, Amaral KDS (2011) Weight-length relationship, condition factor and blood parameters of farmed Cichla temensis Humboldt, 1821 (Cichlidae) in central Amazon. Neotrop Ichthyol 9(1):113-119

Vázquez GR, Guerrero GA (2007) Characterization of blood cells and hematological parameters in Cichlasoma dimerus (Teleostei, Perciformes). Tissue Cell 39:151-160. doi:10.1016/j.tice.2007.02. 004

Wepener V, Van Vuren JH, Dupreez HH (1992) Effect of manganese and iron at a neutral and acid $\mathrm{pH}$ on the hematology of the banded Tilapia (Tilapia sparrmani). Bull Environ Contam Toxicol 49(4): 613-619 